\title{
Determination of malachite green and leucomalachite green residues in rainbow trout in Sanandaj City
}

Reza Rezaee ${ }^{1}$, Afshin Maleki ${ }^{2}$, Mahdi Safari ${ }^{3}$, Behzad Shahmoradi ${ }^{4}$, Ali Jafari ${ }^{5}$, Omid Giaghi ${ }^{6}$, Shiva Zandi $^{7}$, Nikoo Khaledyan ${ }^{8}$, Shima Sharifi', Shadieh Mohammadi ${ }^{10}$

1.Assistant Professor, Environmental Health Research Center, Research Institute for Health Development, Kurdistan University of Medical Sciences, Sanandaj, Iran. ORCID ID: 0000-0003-2314-6697

2.Professor, Environmental Health Research Center, Research Institute for Health Development, Kurdistan University of Medical Sciences, Sanandaj, Iran. ORCID ID: 0000-0001-8261-8717

3.Assistant Professor, Environmental Health Research Center, Research Institute for Health Development, Kurdistan University of Medical Sciences, Sanandaj, Iran. ORCID ID: 0000-0003-0347-9283

4.Associate Professor, Environmental Health Research Center, Research Institute for Health Development, Kurdistan University of Medical Sciences, Sanandaj, Iran. ORCID ID: 0000-0002-2120-4518

5.Assistant Professor, Department of environmental health engineering, faculty of health and nutrition, Lorestan University of Medical Sciences, Khorramabad, Iran. ORCID ID: 0000-0001-8761-6323

6.Associate Professor, Environmental Health Research Center, Research Institute for Health Development, Kurdistan University of Medical Sciences, Sanandaj, Iran. ORCID ID: 0000-0001-9256-3115

7.Laboratory expert, Environmental Health Research Center, Research Institute for Health Development, Kurdistan University of Medical Sciences, Sanandaj, Iran. ORCID ID: 0000-0001-8349-5595

8.Student Research Committee, Kurdistan University of Medical Sciences, Sanandaj, Iran. ORCID ID: 0000-0003-1227-4407 9.Student Research Committee, Kurdistan University of Medical Sciences, Sanandaj, Iran. ORCID ID: 0000-0001-9427-8297 10.Assistant Professor, Environmental Health Research Center, Research Institute for Health Development, Kurdistan University of Medical Sciences, Sanandaj, Iran., (Corresponding Author), Tel: 087-33664658, Email: Shadiehmohammadi@yahoo.com, ORCID ID: 0000-0002-0711-4305

\section{ABSTRACT}

Background and Aim: Malachite green (MG) is an organic compound which his used as a dye in textile industry. This compound is applied incorrectly and illegally in aquiculture as an antimicrobial agent. This compound has mutagenic and carcinogenic effects.

Materials and Methods: In this study we determined the concentrations of MG and leucomalachite green (LMG) in the muscle tissue of 90 rainbow trouts (Oncorhynchus mykiss) collected from the local markets in Sanandaj City within a period of six months in 2018. In order to measure the residues of MG and LMG, we used enzyme-linked immunosorbent assay (ELISA) based on the European Union Decision 2002/657/EC.

Results: The results showed presence of MG and LMG in all 90 samples: The residues of MG in the samples were as follows: $1-2 \mu \mathrm{g} / \mathrm{Kg}$ in $41(6.45 \%)$, more than $2 \mu \mathrm{g} / \mathrm{Kg}$ in $45(50 \%)$ and less than $1 \mu \mathrm{g} / \mathrm{Kg}$ in 4 samples (4.4\%). Furthermore, the residues of LMG in the samples were as follows: more than $2 \mu \mathrm{g} / \mathrm{Kg}$ in $13(45.14 \%), 1-2 \mu \mathrm{g} / \mathrm{Kg}$ in $67(44.74 \%)$ and less than $1 \mu \mathrm{g} / \mathrm{Kg}$ in 10 samples (11.11\%) . Moreover, the limit of detection (LOD) in the method was $0.43 \mu \mathrm{g} / \mathrm{Kg}$.

Conclusions: It is concluded that MG is illegally applied in fish farms, which can be a threat to human health and the environment.

Keywords: Malachite green, Leucomalachite green, Rainbow trout, ELISA, Sanandaj Received: Jan 18, 2020

Accepted: Mar 10, 2020

How to cite the article: Reza Rezaee, Afshin Maleki, Mahdi Safari, Behzad Shahmoradi, Ali Jafari, Omid Giaghi, Shiva Zandi, Nikoo Khaledyan, Shima Sharifi, Shadieh Mohammadi. Determination of Malachite Green and Leucomalachite Green Residues in Rainbow Trout Offered in the City of Sanandaj. SJKU. $2020 ; 25$ (3): 61-71.

Copyright ( 2018 the Author (s). Published by Kurdistan University of Medical Sciences. This is an open access article distributed under the terms of the Creative Commons Attribution-Non Commercial License 4.0 (CBYNC), where it is .permissible to download, share, remix, transform, and buildup the work provided it is properly cited. The work cannot be used commercially without permission from the journal 


\section{تعيين ميزان باقيمانده مالاشيت كرين و لكومالاشيترين در ماهىهاى قزل آلاى رنكين كمان}

\section{عرضهشده در سطح شهر سنداج}

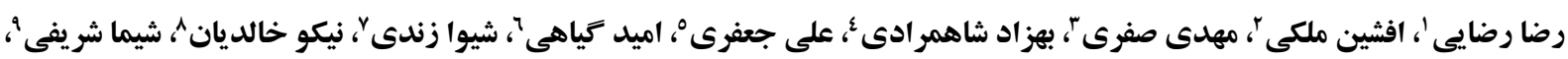

شاديه محمدى .

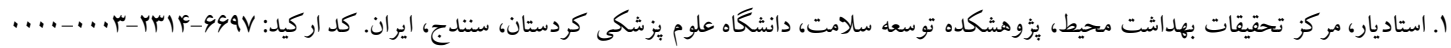

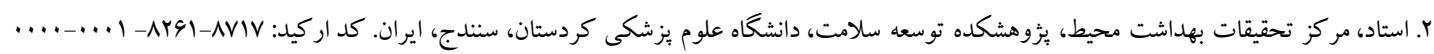

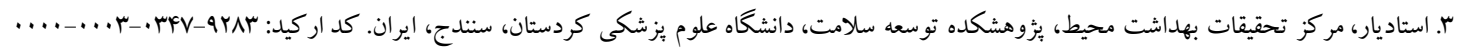

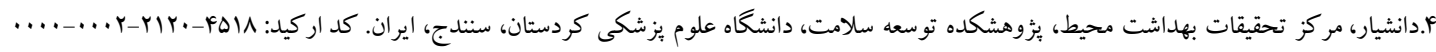

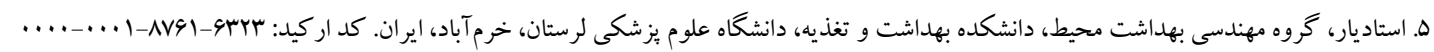

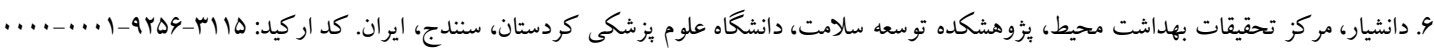

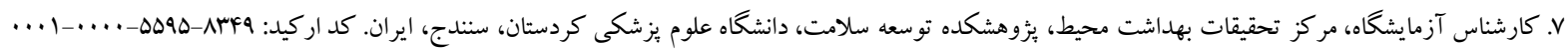

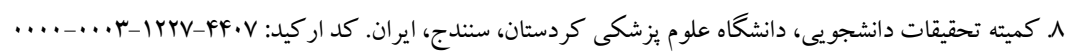

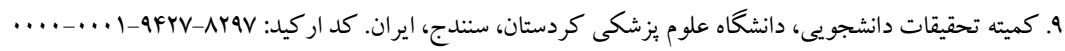
•ا. استاديار، مركز تحقيقات بهداشت محيط، بروهشكده توسعه سلامت، دانشگاه علوم يزشكى كردستان، ستندج، ايران (نويسنده مسئول)، تلفن:

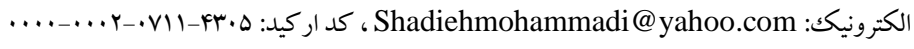

جكيuه

زمينه و هدف: مالاشيت گرين يكك تركيب آلى رنككزا در صنعت نساجى است و بهصورت نادرست و غيرمجاز بهعنوان يكك داروى ضد ميكروبى در آبزى يرورى مورد استفاده قرار مى گيرد. اين ماده داراى اثرات سوء مو تازنى و كارسينوزنى است. هدف از

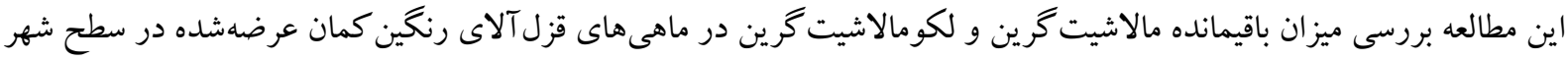

مواد و روشها: در اين مطالعه غلظت مالاشيت گرين(MG) و لكومالاشيت گرين (LMG) در بافت عضلانى ·9 نمونه ماهى

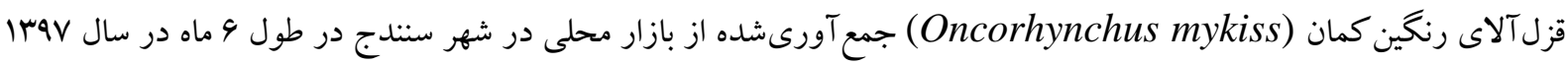

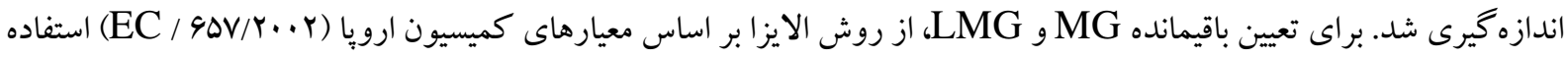

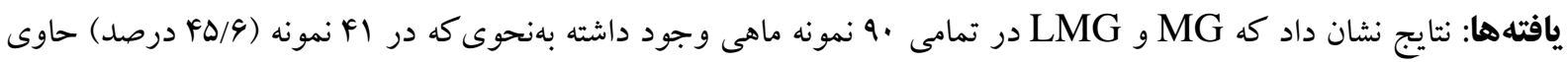

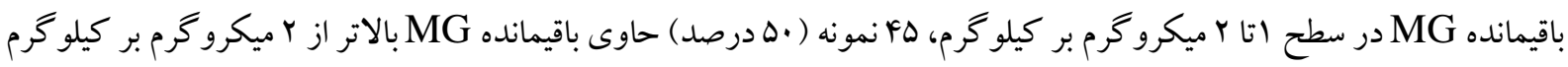

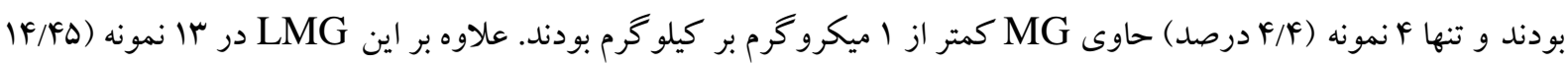

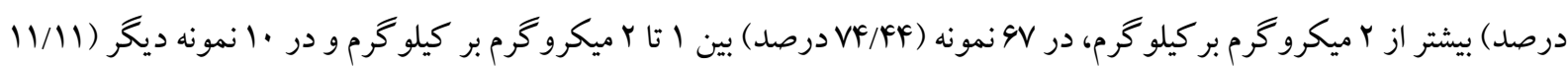

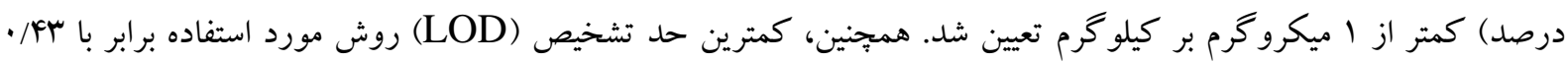
ميكرو گرم بر كيلو گرم تعيين گرديد.

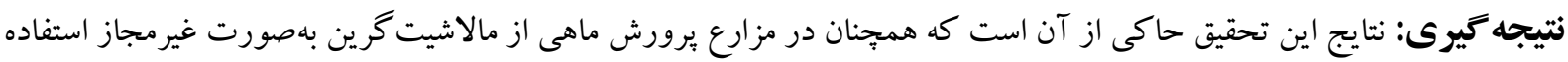
مى شود كه اين مسئله مى تواند بهعنوان خطرى بر ایى سلامت عمومى و تهليدى براى محيطزيست مطرح باشد.

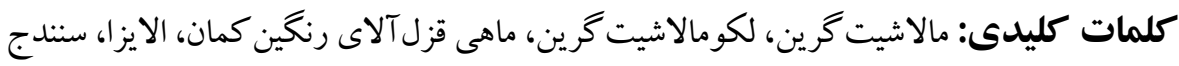

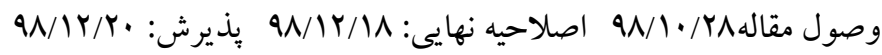


موجب تلفات بالا بهويزه در مرحله جنينى و لاروى

مى گردد(ه). تاكنون مطالعات متعددى در ارتباط با اثرات سوء بهداشتى استفاده از MG در ماهى انجام گرديده كه نتايج آنها نشان داده اين ماده اثرات مخربى در كليهها، كبد و طحال ايجاد مىنمايد، بعلاوه از اين ماده بهعنوان يكك تركيب شيميايى كه احتمالاً اثرات موتازنى (جهشزايى) و كارسينوزينى (سرطانزايى) نيز دارد، ياد شده است(1). همجِين ثابت شده اين ماده مى تواند با ايجاد اختلالاتى نظير شكستخى و به هم جِبيدن كروموزومها، بهعنوان يكك عامل تراتوزن (اثر منفى بر جنين) عمل نمايد و لذا وجود آن در هر سطحى در ماهى مىتواند اثرات سوء بهداشتى ايجاد نمايد(r). شايد عينى ترين اثر MG در آبزىيرورى اثرات اين ماده در مهار آنزيمهاى تنفسى ميتو كندرى باشد كه به همين علت در برخى منابع از آن بهعنوان سم تنفسى يادشده كه مى تو اند باعث بروز اختلالات تنفسى و خفكى در ماهيان گردد. اين ماده شيميايى پِ از جذب در بافتهاى بدن به لكو -

مالاشيت گرين (LMG; Leucomalachite green) احياء مىشود كه يك ماده جربىدوست بوده و داراى خاصيت ماند كارى طو لانى بهويزه در عضلات است. عمده خواص سمى مالاشيت گرين را به اين متابوليت احياشده نسبت مىدهند و به همين دليل همواره نگخرانىهاى انتقال آن به مصرف كنند كان وجود دارد(V, 9) و مشخص شده كه تا 9 درصد از MG جذبشده توسط بافتهاى عضلانى بهورت LMG و MG و انباشته مى گردد. باقيمانده در سرم، كبد، كليه، عضلات و ساير بافتهاى ماهى گزارش شده است(^). با توجه به اثرات جهشزايى و سرطانزايى ، استفاده از اين ماده در سراسر جهان هرگز بهعنوان MG يكك دارو در داميزشكى در حيواناتى كه به مصرف غذايى
تكثير و يرورش آبزيان، بهويزه ماهىهاى سرد آبى در اكثر نقاط ايران درحالتوسعه بوده و ازجمله موانع و مشكلات اساسى در اين زمينه، تلفات بالا بخصوص در دوران انكوباسيون تخم در مراكز تكثير است. برخى از ميكروار كانيسمها همانند باكترىها، قارجها و تككياختها ازجمله عوامل بيمارىزايى هستند كه معمولاً در مراكز تكثير و يرورش آبزيان باعث ايجاد تلفات و كاهش توليد مى كردند. به همين دليل نياز به استعمال و مصرف دارو براى يرورش آبزيان همواره امرى ضرورى و غيرقابلاجتناب

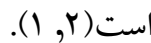
ازجمله داروهاى برمصرف در آبزى يرورى مالاشيت كرين (MG; Malachite green) رنگك كاتيونى ترىفنيلمتان از فرآوردههاى رنكى آنيلين است كه بهعنوان عامل رنغكزا در صنعت نساجى استفاده

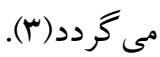
MG به دليل خواص ويزه، از سال 194 دور صنعت شيلات و آبزى يرورى مورداستفاده قرار كرفته؛ اما به دليل كشف اثرات زيانبار آن، بيش از دو دهه است كه استفاده از آن در بسيارى از نقاط دنيا ممنوع گرديده است. باوجود ممنوعيت، به دليل هزينه بايين و كارايى بالا همجنان بهصورت MG غيرمجاز در صنعت آبزىيرورى براى كنترل انگلهاى خارجى و عفونتهاى قارجى در تخم ماهى، لارو ماهى و

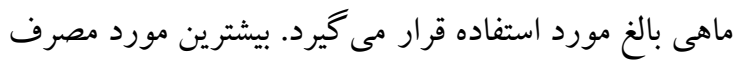
اين ماده، مقابله با نوعى قارج از خانو اده سا يرولخنيا است(F). قارج سا يرولخنيا يكى از مهم ترين عوامل بيمارىزا در يرورش ماهيان آب شيرين محسوب مىشود كه بهصورت طبيعى در منابع تأمين كنندهى آب مراكز تكثير ماهى وجود داشته و 
اين زمينه مى تواند، در تدوين يكك برنامه هدفمند در راستاى

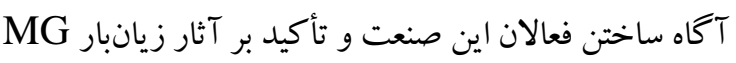
بسيار مؤثر و مفيد باشد، همجنين زمينه حذف اين ماده را از فهرست داروهاى مصرفى در مراكز يرورش ماهى ايجاد نمايد و شرايط را براى جايكزينى داروهاى بىخطر فراهم سازد. هدف از اين مطالعه تعيين ميزان MG و LMG در ماهى

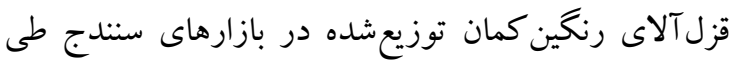
يك دوره 9 ماهه در سال VIr I بوده است.

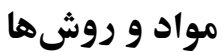

روشهاى مختلفى براى تشخيص MG و LMG در مواد غذايى ازجمله فر آوردههاى دريايى وجود دارد كه ازجمله آنها روش كروماتو گر افى با كارايى بالا ) HPLC; High (If)(Pressure Liquid Chromatography استكتروفتومترى جرمى(1))، آشكارسازهاى فلوروسن(19) و الايز|(IV) است. در اين ميان روش الايزا به دليل سرعت

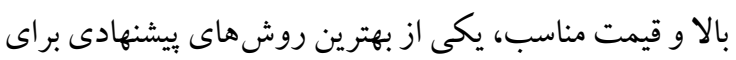
اندازهيرى MG و MMG باقيمانده در ماهيان يرورشى است(1)(1). در اين مطالعه از روش الايزاو بر اساس معيارهاى كميسيون ارويا (Y..r. ED/ استفاده گرديد(19) و محلولهاى استخراج و كيت الايزا مخصوص از شركت طب سينا نماينده Europroxima هلند در ايران تهيه شد. حجم نمونه و روش نمونهبردارى در اين مطالعه تعداد نمونهاى مورد آزمايش با توجه به مطالعات مشابه قبلى تعيين گرديد( •r, I). بر اين اساس تعداد هو نمونه تصادفى ماهى قزل آلاى رنخين كمان عرضهشده در. سطح شهر سندج انتخاب شد كه با دو بار تكرار انجام
انسان مىرسند، تائيد نمى گردد و حضور MG و LMG در مو اد غذايى، حتى در سطوح بايين، منجر به رد محصول مى EC; ) شود(9). بر اساس استاندارد كميسيون اتحاديه ارويا European Commission و وازمان (WHO; World Health Organization) خواربار و كشاورزى ملل متحد Food Agriculture) (FAO; Organization در بافت عضلانى انواع ماهى، ب ميكروگرم بر LMG كيلو گرم در نظر گرفته شده است (11, • (1). در كشور ايران نيز استفاده از MG در صنعت آبزىيرورى ممنوع اعلام شده و سازمان استاندارد ايران نيز همان ميكرو گرم بر كيلو گرم در عضلات ماهى را بهعنوان حداكثر دوز مجاز اعلام نموده است و در بى ممنوعيت استفاده از و و بهمنظور تأمين جايكزين مناسب براى آن تاكنون تحقيقات زيادى در ايران و جهان انجام شده و اثرات مفيد استفاده از موادى جون آباكسيزنه، آلويتا، سولفات مس، يرمنكنات يتاسيم، آويشن، فرمالين و غيره اثبات گرديده است(9). يكى از جايخزينهاى شناختهشده براى MG، ير اكسيدهيدروزن غذا و داروى ايالات متحده آمريكا FDA; Food and (T) Drug Administration) كم خطر دستهبندى نموده است(Y ( ). از ديخر مواد جايخزين MG ماده ضد قارج و ضد باكترى مورد تائيد مؤسسه استاندارد و تحقيقات صنعتى ايران، سازمان داميزشكى كشور و اداره نظارت بر مواد غذايى، قرار گرفته است. مطالعات انجامشده نشان مىدهد آلويتا با غلظت يكك گرم در ليتر مىتواند جايخزين مناسبى براى MG باشد(r)). نتايج مطالعات در 
نموده و به باقيمانده آن بميلىليتر دى كلرومتان اضافه و سبس در جريان ملايم نيتروزن در دماى •هدرجه سلسيوس خشك بـ گرديد. در مرحله بعد به باقيمانده خشك شده هr ميكروليتر متانول با درجه خلوص .. إدرصد اضافه و ماده خشكشده در آن حل گرديد. به مخلوط حاصل، هVه ميكروليتر بافر رقيقسازى اضافه و محلول جند دقيقه ورتكس شد و درنهايت •ه ميكروليتر از اين محلول در اندازهيرى با كيت الايزا

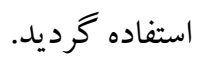

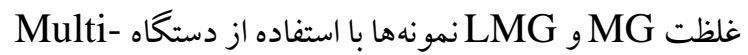
Fa. مر طولموج Synergy-HTX مدل mode reader

$$
\text { نانومتر تعيين گرديد. }
$$

كمترين حد تشخيصى(LOD; Limit of Detection) روش كري برابر با به/• ميكرو گرم بر كيلو گرم بود. حد تشخيص روش با تعيين ميانگين ·r نمونه شاهد كه هر نمونه ب بار آناليز و انحراف معيار دادهها اندازهيرى شد، مشخص گرديد. در شكل ا توانايى تشخيص MG و LMG در روش الايزا ارائه گرديده است. بر اين اساس حد تشخيصى روش به كاربرده شده در اين مطالعه با استفاده از كيت الايزا در مورد وجود

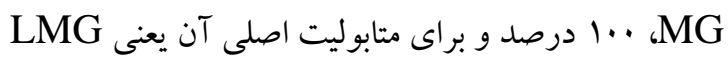
V vرصد تعيين گرديد(1).
آزمايشها، درمجموع •11 نمونه مورد آزمايش و ارزيابى قرار گرفت. جهت انتخاب نمونهها، كل مراكز توزيع ماهى قزل آلاى رنخين كمان در سطح شهر سندج شناسايى و از بين آنها • ا مركز بهصورت تصادفى انتخاب و از هر مركز 9

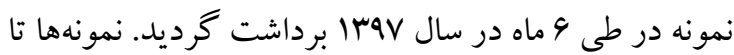
زمان انجام آزمايش ها در شر ايط دمايى مناسب نخهارى شد.

$$
\text { روش انجام آزمايشها }
$$
در ابتدا نمونههاى ماهى قزل آلاى رنخين كمان كاملاً شسته و يوست گيرى شده و عضلات آنها بهصورت مجزا هموزن كرديد. استخراج نمونهها مطابق دستورالعمل كيت شركت Europroxima براى اين منظور ب گرم از نمونه عضله ماهى، وزن و توسط

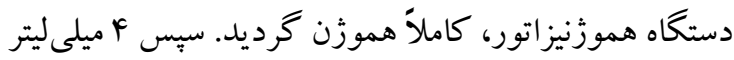
محلول Y مولار نمكك NaCl در بافر PBS به آن اضافه و به مدت يكك دقيقه با ورتكس هم زده شد. در ادامه r ميلىليتر اسيد كلريدريك ا مولار به آن اضافه و يكك دقيقه با ورتكس مخلوط گرديد. نمونههاى حاصل در دماى اتاق با دور ب... RPM به مدت هدقيقه سانتريفوز شد و سبس F ميلىليتر محلول زير لايه جربى را برداشته و ه ميلىليتر دى كلرومتان به آن اضافه شد. در ادامه كار محلول به مدت ه دقيقه با دور

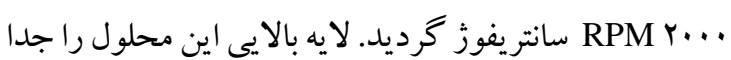




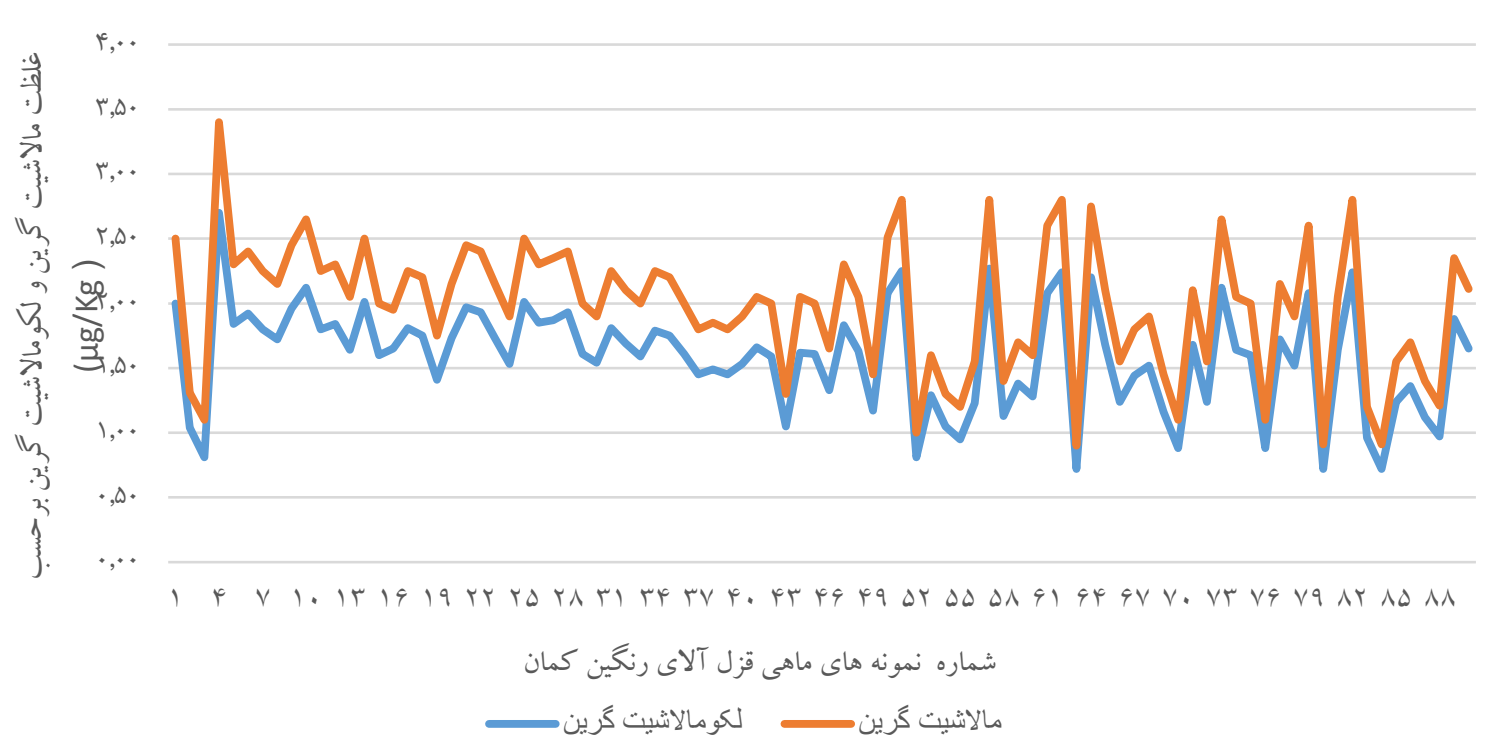

شكل ا. توانايى تشخيص مالاشيت كرين و لكومالاشيت كرين به روش الايزا

دادر rا نمونه (\&MG

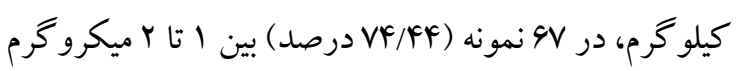

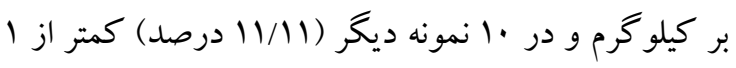

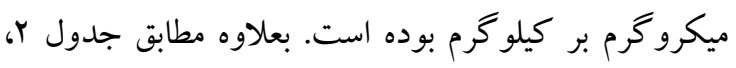

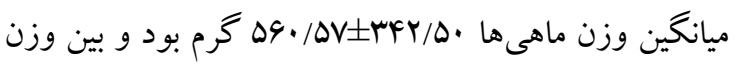
ماهىها و مقادير غلظت MG و LMG رابطه معنىدارى مشاهده نشد (ه>/P> (ه). در مقايسه مقادير غلظت MG و

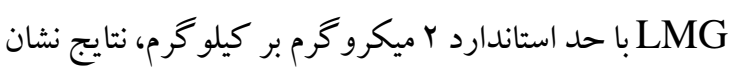
داد غلظت MG تفاوت معنىدارى با استاندارد نداشته

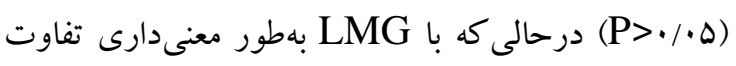
مشاهده شد و مقادير بهدست آمده كمتر از حد استاندارد بود . $(\mathrm{P}<\cdot /, \cdot 1)$

\section{روش تجزيه وتحليل دادهها}

بهمنظور آناليز آمارى دادهها از نرمافزار 21 و روش ضريب همبستكى بيرسون و تى يكك نمونه استفاده شد.

يافتهها

مطابق يافتهاى حاصل از اين مطالعه، جدول او شكل r نشان داد كه ميانگين و انحراف معيار غلظت MG و LMG به به بـ

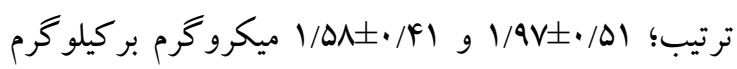
بود. همجنين مطابق اين نتايج أF نمونه (Fo/9 درصد) حاوى باقيمانده MG در سطح ب-1 ميكرو گرم بر كيلو گرم،

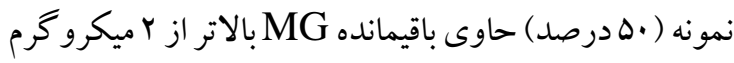
بر كيلو گرم بودند و تنها \& نمونه (F/F درصد) حاوى (F) كمتر از 1 ميكروگرم بر كيلو گرم بودند. علاوه بر اين 
جدول ا. غلظت مالاشيت كرين و لكومالاشيت كرين در • 9 نمونه ماهى قزل آلاى رنكين كمان توزيعشده در شهر سندج

\begin{tabular}{|c|c|c|c|c|c|c|c|}
\hline$\%$ RSD & $\begin{array}{c}\text { كمترين } \\
\text { غلظت }(\mu \mathrm{g} / \mathrm{kg})\end{array}$ & 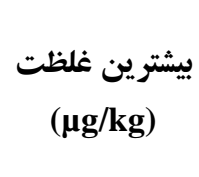 & $\begin{array}{l}\text { ميانكين } \\
(\mu \mathrm{g} / \mathrm{kg})\end{array}$ & درصد & تعداد نمونهها & 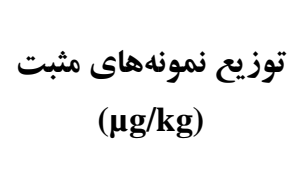 & آلاينده \\
\hline$r / 19$ &.$/ 9$ &.$/ 91$ & $\cdot / 9 \cdot 0$ & $k / F$ & f & $<1$ & \\
\hline$r / A \cdot F$ & 1 & r & $1 / 94$ & $r \Delta / 9$ & +1 & $1-r$ & \\
\hline r/gkr & $r / . \Delta$ & $r / q$ & $r / T V \Delta$ & $\Delta$. & is & $r<$ & \\
\hline$r / 4 r$ & $\cdot / v r$ &.$/ 9 V$ & $\cdot / \wedge \Delta$ & $11 / 11$ & 1. & $<1$ & \\
\hline$r / \Delta)$ & $1 / \cdot 4$ & r & $1 / \Delta \Lambda$ & $V F / F F$ & qV & $1-r$ & is \\
\hline$r / 9$ & $r / .1$ & $r / V$ & $r / M \Lambda$ & $\mid F / F \Delta$ & ir & $r<$ & \\
\hline
\end{tabular}

لكومالاشيت كرين هـ مالاشيت كرين

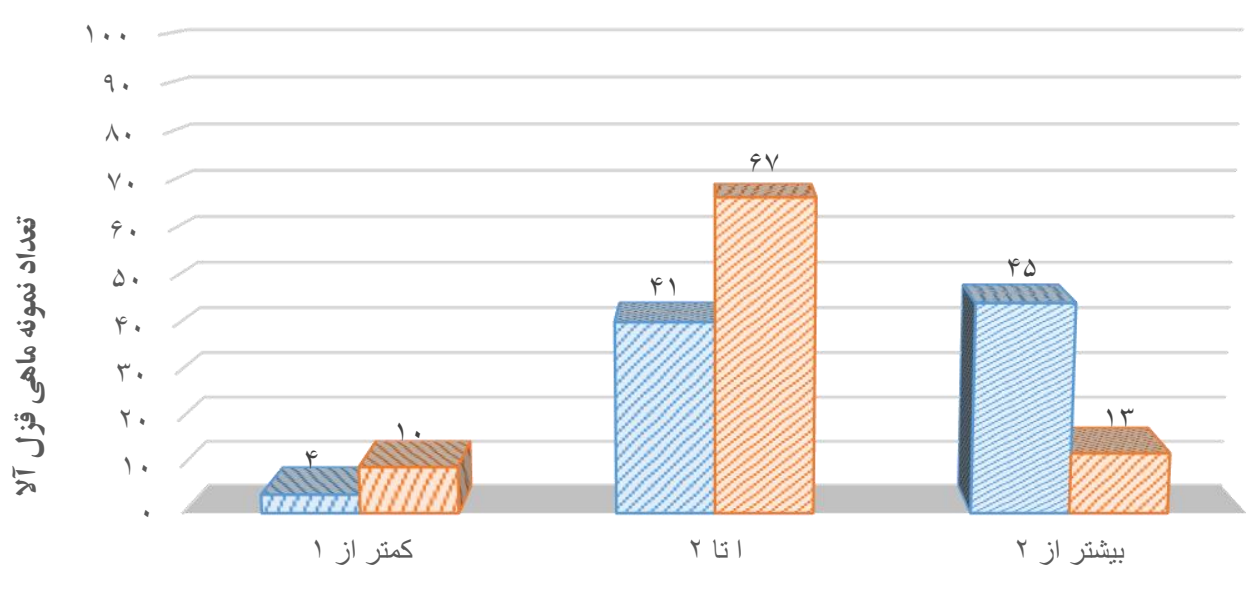

غلظت مالاشيت كرين و لكومالاشيت كرين بر حسب ( )

شكل ז. غلظت مالاشيت كرين و لكومالاشيت كرين در .q نمونه ماهى قزل آلاى رنكين كمان توزيعشده در شهر سندج 
جدول †. مقايسه مقادير غلظت مالاشيت كرين و لكومالاشيت كرين در ماهى قزل آلاى رنكين كمان با استاندارد

\begin{tabular}{|c|c|c|c|c|c|c|}
\hline $\mathbf{p}$ & $\mathbf{t}$ & تفاوت ميانعين & 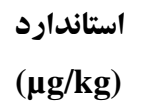 & انحر اف معيار & $\begin{array}{c}\text { ميانكين } \\
(\mu \mathrm{g} / \mathrm{kg})\end{array}$ & متغير \\
\hline$\cdot 19 \cdot 1$ &.$/ 01 F$ & $-\cdot / \cdot r V$ & r & $\cdot / 01$ & $1 / 9 V$ & مالاشيت كرين \\
\hline$\cdot / \cdots$ & $9 / 94$ & $-\cdot / 410$ & r & $\cdot / 41$ & $1 / \Delta \Lambda$ & لكومالاشيت كرين \\
\hline
\end{tabular}

ماهى ايران جمع آورى شدند، حاوى باقيمانده بيش از حد

استاندارد MG بودند(YF). در مطالعه Motafeghi و

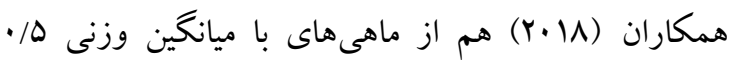
كيلو گرمى استفاده شد كه بين وزن ماهىها و مقادير غلظت و MG اين در مقايسه با مطالعاتى كه از ساير وزنها نيز استفاده كرده بودند(YD) باز داراى تفاوت معنى دارى با غلظت MG نبودة، بنابراين وزن نمىتواند عامل تعيين كنندهاى از نظر غلظت در گوشت ماهى باشد. در نتايج بدست آمده از اين مطالعه ميانگين ميزان MG بيشتر از LMG كزارش گرديد كه دليل آن به فر آيند متابوليكى حضور اين آلاينده در بدن ماهى مربوط مى شود، بطوريكه مشخص شده كه تا •9 درصد از MG جذبشده توسط بافتهاى عضلانى بهصورت

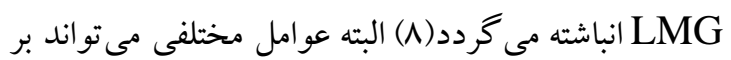
تجمع اين ماده در بافت تبديل آن به LMG تاثير گذار باشد. از جمله اين عوامل مىتوان به غلطت MG در آب، مدت زمان در معرض قرار گيرى ماهى با آن، دما و pH آب، مو اد آلى و يونهاى موجود در آب و يونها اشاره كرد)

در مطالعه حاضر نوسانات مقادير MG و MGG بايين بوده و مهمترين علت آن مى تواند برداشت نمونهها از نقاط متمركز باشد بطوريكه در مطالعاتى كه تفاوت در نقاط نمونهبردارى
نتايج حاصل از اين مطالعه نشان داد كه تمامى نمونههاى

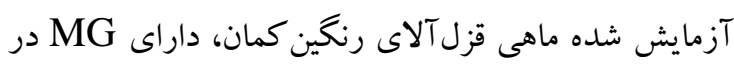

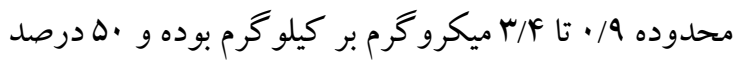
از اين نمونهها داراى مقادير بيشتر از حد مجاز تعيينشده ميكرو گرم بر كيلو گرم) بودند. نتايج حاصل از اين مطالعه با نتايج اكثر مطالعاتى كه در اين زمينه در ساير نقاط ايران انجام شده همخوانى دارد و حاكى از آن است كه يرورش دهند ماهى به دلايلى ازجمله قيمت ارزان، مؤثر و در دسترس بودن، همجنان از MG در بحث كنترل بيمارىهاى ماهىها در مزارع برورشى استفاده مىنمايند (·, (1). با اين وجود ميزان حداكثر MG در مطالعه حاضر (q/ץ ميكرو گرم بر كيلو گرم) در مقايسه با بسيارى مطالعات انجام شده داخلى و خارجى (r, مراتب كمتر مىباشد كه اين امر نشان از ملزم كردن مراكز يرورش ماهى به رعايت استانداردها و يايش دورهاى سازمانهاى ذى ربط مىباشد، البته در مقايسه با نتايج اين مطالعه و مطالعات مشابه در برخى مطالعات، سختخيرى و الزامات قانونى بسيار بيشتر بودهو ميانگين وجود MG بسيار كمتر از اين مقادير گزارش شده است(r(Y). در مطالعه Adel و

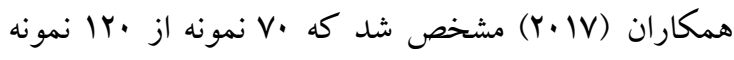

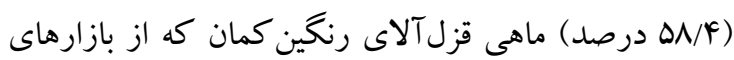


متأسفانه همجنان در مزارع برورش ماهى ايران استفاده

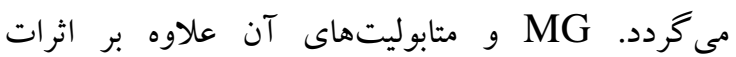
زنوتو كسيك و سرطانزايى براى انسان، مى توانند بهعنوان

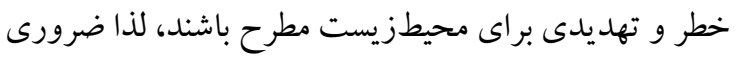

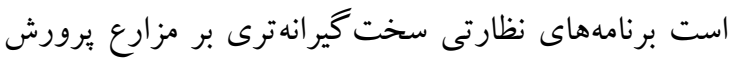
ماهى صورت گيرد.

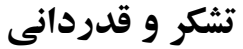

يزروهش حاضر در قالب طرح يزوهشى مصوب در مركز تحقيقات بهداشت محيط دانشكاه علوم يزشكى كردستان در

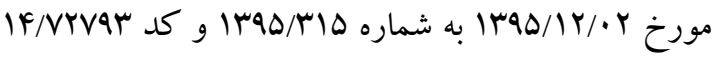
انجام شده است. كليه نويسند گان اين مقاله از حمايتهاى مالى معاونت تحقيقات و فناورى دانشگاه علوم بز شكى إنى كردستان كمال تشكر و قدردانى رادارند.
وجود داشت اختلافات مقادير اندازهيرى بيشتر بود(YD). اين نتيجه مرتبط با كيفيت متفاوت آب مراكز برورش ماهى مى باشد، زيرا اخر شرايط براى رشد قارجها بخصوص قارج سايرولخنيا زياد باشد استفاده از MG نيز بيشتر خواهد شد. يعنى بطور كلى در نمونهايى كه ميزان MG بيشتر بوده بيانگر وجود آلودگى قارجى بيشتر مىباشد. در نتايج اين يُزوهش نشان داده شد در بيش از •ه درصد نمونههاى مورد بررسى غلظت MG اندازهگيرى شده بيش از مقادير استاندارد (ץ ميكرو گرم بر كيلو گرم) مىباشد يعنى با وجود ممنوعيت استفاده از آن توسط سازمانهاى مربوطه، بعلت ارزان بودن وخو اص قارج كشى هنوز استفاده زيادى دارد كه با ارائه جايگزينى مناسب اين روند قابل حل مىباشد؛ تاكنون تلاشهاى زيادى هم در اين زمينه انجام شده بطوريكه K و همكاران (YlQ Keykha همكاران (·r.1) از آب اكسيزنه و آويشن(Y) بعنوان جايخزين MG استفاده كردهاند، هرجند كه در اين مطالعه نيز مقايسه مطالعات انجام شده حاكى از آن است كه در سالهاى اخير استفاده از MG در مزارع برورشى ماهى كاهش يافته است، اما بايد حذف كامل و جايگزينى اين ماده با مواد كم خطرتر مورد توجه باشد و براى اين منظور بايشهاى منظم و برنامههاى نظارتى بيشترى بر مزارع برورشى آبزيان

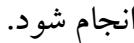

\section{نتيجه كيرى}

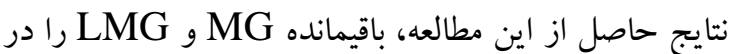

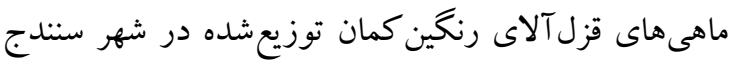
نشان داد و اثبات نمود كه علىرغم ممنوعيت اين ماده، 
1.Fallah AA, Barani A. Determination of malachite green residues in farmed rainbow trout in Iran. J. Food Cont. 2014:40:100-5.

2. Jennings S, Stentiford G, Leocadio A, Jeffery KR, Metcalfe JD, Katsiadaki I, et al. Aquatic food security: insights into challenges and solutions from an analysis of interactions between fisheries, aquaculture, food safety, human health, fish and human welfare, economy and environment. FISH FISH.2016; 17(1): 893-938

3.Rohani Sh KM, Shokri A, Ebrahimzadeh Mousavi H, Soltani A, , Rostamibeshman M. A study of the effect of some Iranian herbal essences against saprolegin Spp. Mycophathologia. 2009;25(3).62-9.

4.Salehi M, Soltani M, Hosseini SP. Effects of antifungal activity of Daenensis thyme (Thymus daenensis) and Mentha (Mentha longifolia) essential oils on rainbow trout) eggs hatchability. IJAAH. 2016; 2(2) 97-107

5.Shin S, Kulatunga D, Dananjaya SH, Nikapitiya C, Lee J, Zoysa M. Saprolegnia parasitica Isolated from Rainbow Trout in Korea: Characterization, Anti-Saprolegnia Activity

and Host Pathogen Interaction in Zebrafish Disease Model. Mycobiology. 2017 ; 45(4): 297-311

6.Srivastava S, Ranjana S, Roy D. Toxicological effects of malachite green. AQUAT TOXICOL. 2004; 66( 3): 319-329.

7.Andersen WC, Turnipseed SB, Roybal JE. Quantitative and confirmatory analyses of malachite green and leucomalachite green residues in fish and shrimp. J. Agric. Food Chem. 2006;54(13):4517-23.

8.Srivastava Sh SR, Roy D,. Toxicological effects of malachite green. AQUAT TOXICOL. 2004;66(3):319-29.

9.Šafařík, I, Šafaříková, M. Detection of low concentrations of malachite green and crystal violet.Water Res. 2002;36(1).196-200.

10.VRC. Veterinary Residues Committee's annual report on surveillance for

veterinary residues in food in UK for 2001 to 2011. Available from http://www.vmd.defra.gov.uk/VRC/reports/annual.html

11.Singha G, Koernera T, Gelinasa J , Abbotta M, Bradya B, Huetb A and etal. Design and characterization of a direct ELISA for the detection and quantification of leucomalachite green. $\mathbf{J}$ Food Addit Contam. 2011; 28(6): 731-739

12.EPA. Rules and Regulations Hydrogen Peroxide; Exemption from the Requirement of a Tolerance, 2000, 65(23).

13.Shykhi mqdm L EM, Hosseini E,. Aluyta substitute malachite green in hatcheries and cold water fish .Environ Sci. 2004;53(2):30-44.

14.Nebot C, Iglesias A, Barreiro R, Miranda JM, Vázquez B, Franco CM, et al. A simple and rapid method for the identification and quantification of malachite green and its metabolite in hake by HPLCMS/MS.Food Cont. 2013;(1)31:102-7.

15.Van de Riet JM, Murphy CJ, Pearce JN, Potter RA, Burns BGJJoAI. Determination of malachite green and leucomalachite green in a variety of aquacultured products by liquid chromatography with tandem mass spectrometry detection. J. AOAC Int. 2005;88(3):744-9.

16.Mitrowska K, Posyniak A, Zmudzki JJJoCA. Determination of malachite green and leucomalachite green in carp muscle by liquid chromatography with visible and fluorescence detection. $\mathrm{n}$. J. Chromatogr. A. 2005;1089(1-2):187-92.

17.Xing W, He L, Yang H, Sun C, Li D, Yang X, et al. Development of a sensitive and group-specific polyclonal antibody-based enzyme-linked immunosorbent assay (ELISA) for detection of malachite green and leucomalachite green in water and fish samples. J. Sci. Food Agric. 2009;89(13):2165-73.

18.Singh G, Koerner T, Gelinas J-M, Abbott M, Brady B, Huet A-C, et al. Design and characterization of a direct ELISA for the detection and quantification of leucomalachite green. J Food Addit Contam. 2011;28(6):731-9. 
19.European Communities. Commission Decision 2004/25/EC, Official. Amending Decision 2002/657/EC as Regards the Setting of Minimum Required Performance Limits (MRPLs) for Certain Residues in Food of Animal Origin. J. EC. 2004, L6, 38-39.

20.Barani A, Tajik H. JIjofp. Malachite green residue in farmed fish in north-west part of Iran. Int. J. Food Prop. 2017; 20(1): 580-585.

21. Tripathi M, Khanna SK, Das MJFC. Surveillance on use of synthetic colours in eatables vis a vis Prevention of Food Adulteration Act of India. J. Food Cont. 2007;18(3):211-19.

22. Fu WS, Zheng KC, Qiu WQ, Wang QL, Fang QM. Investigation and traceability of residual malachite green and its metabolite in freshwater fish. J. Food Saf Food Qual. 2013;11(4):176-182.

23. Bilandzic N, Varenina IK, Kollanovic BS. Oraic D. Zrncic S. Malachite green residues in farmed fish in Croatia. J. Food Cont. 2012; 26:393-396.

24. Adel M, Dadar M, Oliveri Conti G. Antibiotics and malachite green residues in farmed rainbow trout (Oncorhynchus mykiss) from the Iranian markets: a risk assessment. Int. J. Food Prop. 2017;20(2):402-408.

25. Motafeghi F, Javadi I, Allameh S K. Investigation of Malachite green existence in Rainbow trout (Oncorhynchus mykiss) and common Carp (Cyprinus carpio) flesh in the area of North and South of Iran, Haraz and Shahr e Kord. isfj. 2018; 27 (1) :131-137.

26. Sudova E, Machova J, Svobodova Z, Vesely T. Negative effects of malachite green and possibilities of its replacement in the treatment of fish eggs and fish: a review. J.Vet. Med 2007;52:527-53.

27. Safari S, Hashemian F, Rastegar H, Qomi M. Exploring malachite green residues in farmed rainbow trout muscle tissue using high performance liquid chromatography. J. Med. Sci. 2018; 28 (4) :290-296. 28. Keykha S, Gharaei A, Mirdar Harijani j, Ghaffari M, Rahdari A. Antifungal effects of metalonic sumac (rhus coriaria 1.) essential oil on schizothorax zarudnyi eggs. s. Vet. J. 2015; 70 (2): $131-7$

29. Sari A, Akhondzadeh Basti A, Rokni N, Ebrahimzadeh Mousavi H, Soltani M, Gandomi $\mathrm{H}$, et al . Effect of Zataria multiflora Boiss. Essential oil on the Behavior of Vibrio parahaemolyticus in Salted Fish. J. Med. Plants. 2010; 4 (36) :136-144 